\title{
DevSim: A PowerPoint-Based Choose-Your-Own-Adventure Game for Teaching Economic Development
}

Author: Mark Fabian, University of Cambridge

Contact: $\underline{\text { mf723@cam.ac.uk }}$

ORCID: 0000-0003-4675-2526

Funding details: This project was supported by an Australian Government Research Training Program award.

Disclosure Statement: Nothing to disclose

JEL Codes: A2, O1

\section{ABSTRACT (Max 125 words):}

This paper explains how to use a game ("DevSim") built using PowerPoint with an embedded Excel spreadsheet. DevSim plays out key structural changes studied in development economics. It provides a fun way to introduce students to central themes of economic development including industrialization, demographic transition, sources of growth, trade, institutions, and the resource curse. The foundation of the game is a production function, with the class allocating labor and capital to different industries each turn in order to grow their economy. More advanced concepts like trade and institutions are introduced each turn in the form of exogenous shocks.

Keywords (3-5): Development, education, economics, game,

\section{ACKNOWLEDGEMENTS}

The author would like to thank Ryan Edwards and seminar participants at the Brookings Institution for helpful comments. 


\section{DevSim: A PowerPoint-Based Choose-Your-Own-Adventure Game for Teaching Economic Development}

Games are a common and effective teaching tool (Griffin and Butler 2005). Economics educators are blessed with a wealth of games developed to teach many central concepts, such as pit-trading games for teaching market forces (Holt 1996), emissions trading games (Ando and Harrington 2010, Corrigan 2011), monetary policy games (Lengwiler 2010), and rentseeking games (Strow and Strow 2006), among others. Unfortunately, few games exist for teaching concepts in economic development, perhaps because these are relatively complex and multi-faceted. To redress this, I designed and built a game in Microsoft Excel and then Microsoft PowerPoint (henceforth "DevSim") that allows students to pretend that they are citizens of a developing country negotiating a range of economic decisions and challenges. I have used DevSim for the past four years in the early stages of a course covering issues in development policy in order to introduce said issues in a fun and interactive environment. Aside from helping to teach development economics, DevSim also serves as an effective icebreaker early in a semester. This article lays out the construction of DevSim, the concepts it refers to, how to play it, discusses teachable moments and considers how DevSim could be further improved.

DevSim is loosely inspired by turn-based strategy video games, notably Sid Meier's successful Civilization and Alpha Centauri franchises. These put players in charge of a nascent society either at the dawn of human civilization or on a freshly colonized planet. Players are required to grow and advance their society through exploration, construction, research and warfare. The setting of these games is pedagogically helpful because it provides a relatively blank slate to start - a single city in an unexplored area. All the complexities of society are reduced to a few key variables, much like in economic modelling. I had 
previously used such a setting to teach fundamental ideas in political theory. Students pretended that they had emerged from an underground bunker following some apocalypse. They needed to start a new society with few resources and great uncertainty. What kind of political system would they opt for? DevSim adopts a similar approach to teaching development economics. The focus is initially on population dynamics and the economics of agriculture and industrialization. As turns pass things get more complicated and the emphasis shifts to productivity and other determinants of long-run growth, including institutions, trade, and resource management. These are typically introduced through exogenous shocks that are narrated for dramatic effect and accompanied by graphics, making the game more captivating.

DevSim is designed to give a broad overview of the development process. The aim of the course it was developed for was to help students understand the Asian Miracle and the development experience of countries like China (Fogel 2011). It would be less suitable for a course on "Poor Economics" (Banerjee and Duflo 2012) i.e. a course tightly focused on the microeconomics of development and NGO interventions. It could be used as part of such a course to provide a quick high-level background to micro issues.

\section{Design of the Game}

DevSim is not played individually by students in a computer lab. Instead, it is like a game-assisted lecture delivery platform. The class plays the game as a group, making key decisions democratically, with the teacher manipulating the game itself. This allows the teacher to narrate the game, providing additional content, sophistication, and links to course concepts. The class-based format makes DevSim an excellent icebreaker between students in the early stages of a course. It also allows the teacher to point out deep issues at play in 
different choices, with the game acting as a launch pad for discussion. While DevSim is perhaps not as compelling as a solo game like Chair the Fed or something autonomous like pit trading, students seem to find it more compelling than a conventional lecture.

The technical set-up of DevSim begins from a production function. Income (Y) is a function of agricultural, manufacturing, and service-sector output. These in turn are a function of productivity (A), labor (L), and capital (K), as in the Cobb-Douglas production function and Solow growth models. Productivity is in turn a function of technology, human capital, institutions, and infrastructure. These are not actual variables in DevSim, but various events in DevSim bear on them directly and manifest in changes to A. Productivity of course comprises other variables, such as geography (Hausmann 2001) and culture (Tabellini 2010), but these are omitted from DevSim for the sake of parsimony. Students primarily try to maximise their GDP over the course of the game.

Population grows exogenously according to a fertility function that is constructed to illustrate demographic transition. Fertility starts high at 5 births per woman ${ }^{1}$ and declines by 1 each turn. This allows students to see a demographic transition through the middle turns of the game and the beginnings of a demographic onus as they exit the middle-income stage in the final turn. The demography of the population is split into four age groups that can be tracked graphically and numerically on a graph in the Excel sheet: 0-18, 19-36, 37-54 and 55+. Individuals in the youngest and oldest age brackets are classified as dependents and cannot work. However, they do consume food. This is a constraint on growth in the earliest turns of the game and allows for the teaching of Malthusian dynamics. DevSim is played primarily through an Excel-based control panel on the first PowerPoint slide. This panel

\footnotetext{
${ }^{1}$ The gender composition of the economy is fixed at 50/50.
} 
includes a breakdown of total population, workers, and dependents, and tracks the dependency ratio.

Capital is a function of savings, which is exogenously fixed at $0.3 \mathrm{Y}-$ Pop. Population is subtracted from income to reflect subsistence consumption. This allows for a teachable moment in the first turn when the high number of young dependents causes the society to focus entirely on agricultural production and yet barely make enough food to prevent starvation. Teachers can discuss the relationship between fertility and savings: when all production is consumed to feed many children, there is none left to save for investment. This impedes capital formation. However, children are a form of savings in these settings because they will take care of the parents in retirement. As the turns tick over the economy becomes wealthier and so consumption beyond subsistence rises. Savings can be invested in the agricultural, manufacturing, or services sectors to improve productivity therein.

Each turn the class allocates labor and capital to the different sectors with an eye to maximizing their income without starving. This is a relatively straightforward exercise aided by a column that calculates how many workers must be allocated to farming given current agricultural productivity. The fun really starts with the exogenous shocks, which begin from turn 2. These involve a narrative event, such as discovering mineral deposits, and a choice about what to do in response to the event. Choices have consequences, typically for productivity. The narrative events make DevSim engaging and fun while also introducing themes from development economics. In the next section, I move step by step through how to play DevSim and discuss how you can use different opportunities presented by the game to teach certain concepts. 


\section{Playing the Game}

I have uploaded a video of me pretending to teach the game to a class to YouTube. It is available here:

\section{https://www.youtube.com/watch?v=yDxnaONRPSI\&feature=youtu.be}

This paper provides a comprehensive guide to using DevSim, but the video is helpful. I suggest watching it before reading this section. I also recommend reading this section with a copy of the game open so that you can follow the steps. DevSim is not complicated to play, but things need to be done in a specific order each turn. As with most classroom games, some preparation is required for a smooth experience.

The title slide of DevSim introduces the game itself. Run the slideshow, and then click to proceed to slide 2 . It provides the following opening narrative:

You are among 10000 humans kidnapped by aliens and deposited on an island on a foreign planet somewhere in the galaxy. You will have to grow your economy to prosper in this new habitat. Your skills in calculus and essay writing are of little use to you, so you are presently unable to do much besides basic farming (agriculture) and handicrafts (manufacturing). Hopefully your technology, skills, and productivity will improve over time.

Click through to the control panel slide, where you will spend the most time. Click on the Excel sheet to open it. I usually take this opportunity to describe the basic building blocks of the game to the students. I refer them to the income function and to the production functions for agriculture, manufacturing, and services. I don't go through the formulas in each cellthat would be boring and time consuming. I merely mention that they are derived from models that they should be familiar with, like the Solow growth model and Cobb-Douglas production function. I explain that each turn they will have to allocate their labor and capital 
to the different sectors to maximize their income. I point out to them that agriculture has diminishing returns to scale while manufacturing does not. This pertains to Malthusian dynamics (Boserup 1965). Land is a fixed factor of production. As you add more laborers to a fixed amount of land, production increases, but at a diminishing rate because of congestion effects. As such, we want to allocate workers to manufacturing where possible, because it has constant returns to scale and so we will make more money that way.

Close the sheet to return to the slideshow and then click on the "Game Start" Button. This will bring you to a slide with a picture of a handicrafts shop in rural Indonesia that represents a low-level of development. The graphics bring the game to life a bit and communicate the class' development level as the game progresses. All the graphics are either my own photos, drawn using Icons in Microsoft Office, or slavish reproductions of artworks more than 100 years old. This avoids any copyright infringement issues. Click through to the next slide, which describes the problems for turn 0 . The turn slides will inform you about what needs to be done each turn, helping you to remember the game steps.

The class' first objective is to make sure nobody starves, so they will have to allocate some inputs to agriculture to produce at least enough food to feed the whole population. This presents an opportunity to get to know the output report column. Click on the "Return to Control Screen" button and then reopen the Excel sheet. The output column is on the far right. It tracks how much food will be produced depending on how much labor is allocated to farming. The students need to produce at least 10 units of food to feed their population of 10000 people (everything is denominated by '000). You can see in the output columns that this requires 3 laborers at present levels of productivity. Base farming output is $(4 \times \text { farmers })^{0.85}$. The exponent ensures diminishing marginal returns, which allows you to teach Malthusian dynamics on turn 0. By running an eye down the column of farm output, you can see the diminishing returns rapidly taking effect as workers crowd the land. 
Productivity then rises in subsequent turns due to exogenous forces like "learning by doing" and endogenous choices by the class. This allows you to teach why Malthus was wrong long term productivity growth. As you go back to the columns each turn you will be able to point out that diminishing marginals returns don't seem to be as strong anymore, and fewer farmers can feed more population. For now, allocate 3 workers to farming. The remaining 7 workers go to manufacturing.

You will see the functions embedded in the sheet spin various cells. Note income growth first: the economy is underdeveloped. Next note savings and investment funds. Explain how savings is a function of income, representing the amount that you don't consume. Explain subsistence consumption, which is presently a tight constraint and leaves little for investment. Note that the savings cell is cumulative over the course of the game, just like income. The "investment funds" cell equals total savings minus amounts that were invested in previous turns. Quickly appoint a dictator for the turn who decides where to invest the class' very limited capital—agriculture or manufacturing. The returns to investment are largely inconsequential by design, so don't let students get stuck on this decision. If you look at the formulas in cells E5, E6, and E7, which correspond to output from agriculture, manufacturing, and services respectively, you will see that all three share the same return to investment: base output ${ }^{1.0001 \times i n v e s t m e n t}$. This is admittedly unrealistic, but it makes the game much more straightforward to play. Having differential returns to capital by industry would create an optimization problem for students. The same is true if some balance needed to be struck between capital and labour allocations as per isoquant theory. In both cases, the optimization would be time consuming to calculate and this would distract from the broader lessons of the game. Development in DevSim is largely driven by population growth and the agrarian transition. The desirability of capital investment for development is expressed by the different baseline productivities of the three industrial sectors $-\left(4 \times\right.$ farmers $^{0.85}$ for 
agriculture, $(4 \times \text { workers })^{1}$ for manufacturing, and $(20 \times$ professionals $)$ for services. All this being said, making the role of capital in DevSim more realistic and meaningful is desirable and I discuss this in the "extensions" section below.

Once investment is allocated, all that's left is to resolve the turn. Insert the current GDP per capita into the Turn 0 box at the bottom of the sheet under the GDP chart. Then change the turn number from 0 to 1 . Close the sheet and click the "Turn 1" button on the control screen of the slideshow to continue. This order needs to be followed each turn. In full it is:

1. Play out the exogenous shock and adjust dummy variables accordingly

2. Allocate labor to "professionals" (turn 4 onwards)

3. Allocate labor to "farmers"

4. Allocate labor to "workers"

5. Allocate investment funds

6. Write the present GDP/Capita in the relevant box at the bottom of the sheet (starting from turn 1). This allows you to track GDP growth over the course of the game.

7. Increase turn count by 1

8. Close Sheet

9. Click on button associated with the next turn

As with "Game Start" the turn 1 button takes you to a slide with an introductory graphic. Clicking through brings you to the instructions for turn 1 . These instructions narrate key issues in the economy and point to teachable moments. In turn 1, the big story is dramatic population growth owing to high fertility. There are five times as many dependents in the economy as workers. This is a good opportunity to explain the dependency ratio, which is tracked in the control panel. Note that all 10 workers in the economy are required to engage in agriculture to support the population. Note further that subsistence consumption means that 
very little income is left to be saved, which triggers depreciation. Investment is -9 , which means you must destroy some of your investments from last turn.

This is a good opportunity to teach about the relationship between fertility, savings, and poverty (Moav 2005). Growth requires capital accumulation, but if all output is consumed to feed a large household then there are no savings leftover to invest. Yet the impoverished must have many children to overcome high mortality and ensure someone is around to care for them in their old age. This creates a poverty trap. If you have the time and inclination, you can extend this lesson into a discussion of big push theories of poverty reduction and their checkered history (Sachs 2005, Easterly 2006).

Turn 2 is also characterized by high fertility, but the working age population is now larger and so the dependency ratio is not as brutal. A teachable item here is the notion of per capita income. GDP is growing fast owing to growth in the labor force, but GDP per capita remains weak.

Turns 0 and 1 involve you moving through the slides and control panel adjusting variables on autopilot. From turn 2 onwards, the class gets much more involved. The big story in turn 2 is the first exogenous shock. The narrative provided on the slide is as follows:

The Alien's terraform the planet. A new land bridge brings you into contact with a neighboring island and its resident species-the Vulcans. They are few in number, but technologically advanced. You could easily wipe them out with your large population, but they offer you a deal. In exchange for $1 / 4$ of your population in food each turn, they will trade you their advanced technology. You have 3 options: You can...

a) Accept the trade

b) Reject the trade and continue in Autarky 


\section{c) Declare war and take over the island!}

I typically explain that taking Vulcan will alleviate the fixed factor of production constraint imposed by limited land on the class' farming productivity. After that, I let the students decide what they want to do by democratic vote. Each choice is associated with a picture on the right-hand side of the slide. Clicking it will take you to a graphic slide explaining the outcome of the choice. From there, a button will return you to the control screen. Depending on the students' choice, you will need to adjust some of the dummy variables there. If the students trade, then you need to change "Trade with Vulcans" from 0 to 1. This will adjust farm output to reflect the $0.25 * \mathrm{P}$ food traded away each turn and increase overall productivity. You can take this opportunity to discuss comparative advantage and distance from the global technology frontier (Lin and Treichel 2014). If the students declare war, then you need to change "Peace with Vulcans" to 0 . This will increase "Land" to 2, change the returns to scale in farming from diminishing to constant, and reduce productivity growth by removing passive technology and skills transfer (Bernard and Jones 1996). If the students chose Autarky, leave things alone. Regardless of which option the students choose each turn, I typically discuss all three possible outcomes briefly so as to cover all the associated teachable moments. One you've discussed each outcome slide, go to the control panel and adjust the relevant variables. Finally, allocate your workers by identifying how many farmers are required to feed the population from the output table, and then put the remaining workers into factories. Once again appoint a dictator to decide how to allocate investment, then flip the turn count.

I discuss the population pyramid every turn, but especially in turn 3 . The class is about to enter the demographic dividend - a low dependency ratio with a relatively high fertility rate (Lee and Mason 2006). Use the "return to control panel" and "last slide viewed" buttons to move between the turn 3 instructions and the control panel and facilitate this discussion. 
The exogenous shock in turn 3 is the discovery of a deposit of the mineral unobtanium ${ }^{2}$. Students can either:

a) Manage the mining themselves, placing the revenues in a sovereign wealth fund, which will earn interest each turn

b) Transfer the revenues directly to the population, who will consume or invest them in a utility maximizing manner (at least according to some economic theories)

c) Sell the mining rights to the Vulcans in exchange for infrastructure construction

These are all themes from the resource curse literature (Frankel 2012). The sovereign wealth fund generates a lot of revenue in the long run, but the immediate effect of that choice is a civil war prompted by corruption. It is worth discussing that transparent sovereign wealth funds can dampen corruption, but that there is always a lot of political jockeying around them. I use East Timor and Papua New Guinea as case studies (Gould 2010). The civil war destroys the capital stock and no investment takes place this turn. After allocating labor for the turn, note the amount in "Investment Funds" and add it to the "destroyed capital" box in the control panel. This will keep it out of the income cell in following turns. In the aftermath of the civil war, the society establishes some strong political institutions that boost productivity going forward. To affect this in the sheet, adjust the "Institutions" dummy variable in the control panel to 1 . This narrative is an opportunity to discuss the role of institutions in determining long run growth. I try to discuss the notion of institutional turning points following things like civil wars, and the challenge of ensuring that rebels don't simply co-opt extractive institutions for themselves but instead replace them with inclusive institutions that are pro-growth (Acemoglu and Robinson 2012).

\footnotetext{
${ }^{2}$ From the movie Avatar. Again, the reference can and should be adjusted every few years to some popular culture that is more topical.
} 
If the students opt to transfer the revenues to the population, then labor productivity collapses because people don't need to work so hard to get by. I use this outcome to discuss the difference between GDP growth and utility or well-being, and whether they are the same thing (Sen 1999). This relates to how development is defined, which is usually one of the first topics we cover in the course I teach. I mention Keynes' (1931) claim that by the present day, we would all be working 15 hours a week because of increases in productivity. Why hasn't this eventuated? What is the "goal" of development?

The infrastructure trade boosts productivity. I use this option to teach the importance of infrastructure proliferation for economic development and to discuss the way some firms and nations, notably China, negotiate for mining contracts in developing countries (Alves 2013). Infrastructure for mining rights has one advantage over cash - it is visible. This makes it harder to corrupt away mining revenues. This option in DevSim is also relevant to "build, operate, transfer" contracts, where some investor gets an asset operational and then eventually transfers ownership of it to the nation (Tam 1999).

Turn 4 brings several new teachable items. The first is the advent of the demographic dividend, which can be discussed neatly with reference to the population pyramid in the control panel. The second is that the society should by now be solidly industrialized. Farm productivity is such that a relatively small number of workers can feed the whole population, and most of the workforce is in manufacturing. The third is the ongoing role of technology transfer from Vulcan. I use this to discuss the notion of a technology frontier and the costeffectiveness of adopting rather than innovating technology. The latter is an important issue in the middle-income transition, which I cover later in the course (Armstrong and Westland 2016). 
The final teachable item is the emergence of the services sector. The service sector of course exists earlier in development, especially nowadays with the proliferation of call centers (Newfarmer et al 2019). Indeed, the services sector can be larger than the manufacturing sector because of low-skill retail ventures in urban areas. The emergence of the services sector in turn 4 of DevSim instead reflects the emergence of high-end servicesbanks, accountancies, legal firms, engineers, etc.—as a major component of the economy. These are high value-added industries and so the "professionals" employed therein generate 5 times as much output as manufacturing workers. However, there is limited demand for services and so you cannot have more than 1 professional for every 100 units of income that your economy generates. Make sure you allocate professionals before doing anything else in the control panel, because other changes will likely increase income.

Turn 5 marks the end of the game. The demographic bonus is giving way to a demographic onus owing to fertility falling below replacement. If there is time, you can use this opportunity to discuss getting rich before getting old, and the divergent experiences of China and Japan (Luo 2015). You could also discuss migration policy. More dramatically, the exogenous shock of turn 5 is a war for survival against a robot army. Only an economy with an income greater than 3000 has the requisite means to win the fight. Do not allocate the class' labor and capital (that comes after exogenous shocks), simply check whether they clear the income threshold. If they do, then they are victorious, if they fall short, then they lose. Game over. Autarkic strategies and the resource transfer approach will tend towards failure, but I have never had classes choose these options. 


\section{Extensions}

I typically play the game with my classes early in the semester, around the third week of the course, and then refer back to it regularly in later weeks when we cover themes from it in detail. For example, when we study the resource curse, I will open the lecture with a reference to "that time we discovered unobtainium in the PowerPoint game and had to decide what to do with it". DevSim provides a kind of scaffolding that students can fit new concepts to as the course develops and their understanding of economic development grows richer.

Playing the game typically takes me around 45 minutes in an hour-long tutorial. It could easily be played for 90 minutes if you wove in more discussion and explanation. If you had such time, some extensions could be possible. I have considered adding the following elements to the game:

- Integrating geography into productivity. My initial inclination is to do this by way of an exogenous climate change shock that either reduces agricultural productivity or makes it volatile using a random number generator. Perhaps the island the class inhabits could become tropical and some portion of the population could die every turn to Malarial infections. Such diseases were much discussed in the early literature on potential long run determinants of growth (Sachs et al 2001).

- Speaking of disease, introducing a mortality rate would make the discussion of savings and fertility richer and present an opportunity to discuss development beyond GDP growth, notably with reference to the Human Development Index.

- Endogenizing the savings rate would make the game more realistic, but I suspect it would also be a technical headache and lead to time consuming discussions in class with students trying to figure out the optimal savings rate. The point of the output table is to allow you to skip over such calculations as much as possible. 
- Similarly, the reason why capital investment merely increases productivity rather than being entered as a multiplicative term in the production functions is to avoid having to calculate optimal mixes of labor and capital in production on the fly. It might improve the game to have sectoral output depend substantially on optimizing capital and labour allocations and thereby require these calculations. The game would have to be almost completely rebuilt to allow for this. My main misgiving about it is that students might fixate on getting the calculations right (with an eye to maximizing their income), which would distract from other teachable moments. While I endeavored to be build DevSim such that it was a realistic representation of development and economic theory, my priority was to facilitate the easy and fun elaboration of many topics in economic development, rather than to precisely represent theory.

- It would be more realistic and not too painful to replace the greater productivity of manufacturing and service sector workers relative to agriculture with higher output prices for the associated goods and services. One concern I have with this is that students would again get bogged down trying to figure out optimal resource allocations. Standardizing output prices at 1 and simply increasing the output of workers allocated to different tasks cuts out these calculations, which speeds up the pace of the game. It is the narrative events that keep students engaged enough for you to expand on the teachable moments. Few students are gripped by the math.

If someone were to improve DevSim in these or related ways, I would be delighted and am happy to help. As it stands, I have neither the relevant competency nor the necessary time to make further improvements. 


\section{Conclusion}

Games are an excellent way to communicate key concepts in an intuitive and fun manner. They are especially helpful for breaking up dry content with a stimulating aside, and for providing a scaffold onto which more formal elucidation of concepts can be placed. In my experience, DevSim is a valuable addition to an early class in development economics as it gives a broad overview of the themes of the subject. It is worth practicing a few times before class because it is easy to make a mistake in the spreadsheet (save a backup!), but once you get the hang of it the game narrates itself. Instructions in the slides prompts you with changes that need to be made and flags teachable items, and buttons navigate you smoothly around the slideshow. I hope this game is as useful to others as it has been for me. 


\section{Works Cited}

Acemoglu, D. and Robinson, J. (2012). Why Nations Fail. New York, NY: Crown.

Alves, A. (2013). China's "Win-Win" Cooperation: Unpacking the Impact of Infrastructurefor-Resources Deals in Africa. South African Journal of International Affairs, vol. 20, no. 2, pp. 207-226

Ando, A. and Harrington, D. (2006). Tradeable Discharge Permits: A Student-Friendly Game. Journal of Economic Education, vol. 37, no. 2, pp. 187-201

Armstrong, S. and Westland, T. (2016). Escaping the Middle-Income Trap: Trade, Investment and Innovation. In F. Hutchinson and S. Basu-Das (eds.), Asia and the MiddleIncome Trap (Pacific Trade and Development Conference Series - PAFTAD), pp. 207-224. London, UK: Routledge.

Banerjee, A. and Duflo, E. (2012). Poor Economics: A Radical Rethinking of the Way to Fight Global Poverty. New York, NY: Public Affairs.

Bernard, A. and Jones, C. (1996). Technology and Convergence. The Economic Journal, vol. 106, no. 437, pp. 1037-1044.

Boserup, E. (1965). The Conditions of Agricultural Growth: The Economics of Agrarian Change Under Population Pressure. London, UK: Routledge

Corrigan, J. (2011). The Pollution Game: A Classroom Game Demonstrating the Relative Effectiveness of Emissions Taxes and Tradeable Permits. Journal of Economic Education, vol. 42 , no. 1 , pp. $70-78$

Easterly, W. (2006). The Big Push Déjà Vu: A Review of Jeffrey Sachs's The End of Poverty: Economic Possibilities for Our Time. Journal of Economic Literature, vol. 44, no. 1, pp. 96-105

Fogel, R. (2011). The Impact of the Asian Miracle on the Theory of Economic Growth. In L. Costa and N. Lamoreaux, Understanding Long-Run Economic Growth: Geography, Institutions, and the Knowledge-Economy, pp. 311-354. Chicago, IL: University of Chicago Press.

Frankel, J. (2012). The Natural Resource Curse: A Survey of Diagnoses and Some Prescriptions. In R. Arezki, C. Pattilo, M. Quintyn and M. Zhu (eds.), Commodity Price Volatility and Inclusive Growth in Low-Income Countries, pp. 7-34. New York, NY: International Monetary Fund.

Gould, M. (2010). Managing the Mana from Below: Sovereign Wealth Funds and Extractive Industries in the Pacific. Economic Round Up, vol. 1, no. 1, pp. 63-86

Griffin, L. and Butler, J. eds. (2005). Teaching Games for Understanding: Theory, Research and Practice. Champaign, IL: Human Kinetics

Hausmann, R. (2001). Prisoners of Geography. Foreign Policy, vol. 122, no. 1, pp. 44-53

Holt, C. A. (1996). Classroom Games: Trading in a Pit Market. Journal of Economic

Perspectives, vol. 10, no. 1, pp. 193-203 
Keynes, J. M. 1931. Economic Possibilities for Our Grandchildren. In Donald Moggridge (ed.), Essays in Persuasion, pp. 321-32. London, UK: Palgrave.

Lee, R. and Mason, A. (2006). What is the Demographic Dividend? Finance and Development, vol. 43, no. 3, pp. 1-9

Lengwiler, Y. (2004). A Monetary Policy Simulation Game. Journal of Economic Education, vol. 35 , no. 2 , pp. $175-183$

Lin, J. and Treichel, V. (2014). Making Industrial Policy Work for Development. In J.

Salazar-Xirinachs, I. Nübler and R. Kozul-Wright (eds.), Transforming Economies: Making Industrial Policy Work for Growth, Jobs, and Development, pp. 65-78. Geneva, CH: International Labor Organisation

Luo, B. (2015). China Will Get Rich Before It Grows Old. Foreign Affairs, vol. 94, no. 1, pp. $19-24$

Moav, O. (2005). Cheap Children and the Persistence of Poverty. The Economic Journal, vol. 115 , no. 500 , pp. $88-110$

Newfarmer, R.; Page, J. and Tarp, F. (eds). Industries without Smokestacks: Industrialisation in Africa Reconsidered. Oxford, UK: Oxford University Press.

Sachs, J. (2005). The End of Poverty: Economic Possibilities for Our Time. New York, NY: Penguin Press

Sachs, J.; Mellinger, A. and Gallup, J. (2001). The Geography of Poverty and Wealth. Scientific American, vol. 284, no. 3, pp. 70-75

Sen, A. (1999a). Development as Freedom. Oxford, UK: Oxford University Press

Strow, B. and Strow, C. (2006). A Rent-Seeking Experiment for the Classroom. Journal of Economic Education, vol. 37, no. 3, pp. 323-330

Tabellini, G. (2010). Culture and Institutions: Economic Development in the Regions of Europe. Journal of the European Economic Association, vol. 8, no. 4, pp. 677-716

Tam, C. (1999). Build-Operate-Transfer Model for Infrastructure Developments in Asia: Reasons for Success and Failures. International Journal of Project Management, vol. 17, no. 6, pp. 377-382 